\title{
IMPULSE BUYING BEHAVIOUR AT THE RETAIL CHECKOUT: AN INVESTIGATION OF SELECT ANTECEDENTS
}

\author{
Vinish PALLIKKARA (1) ${ }^{1}$, Prakash PINTO ${ }^{\circledR 2}$, Iqbal Thonse HAWALDAR ${ }^{\circledR 3}{ }^{*}$, Slima PINTO (®) 4 \\ 1, 2, ${ }^{4}$ Department of Business Administration, St Joseph Engineering College, Mangaluru, Karnataka, India \\ ${ }^{3}$ Department of Accounting \& Finance, College of Business Administration, Kingdom University, Bahrain
}

Received 13 May 2020; accepted 3 August 2020

\begin{abstract}
The remarkable growth of the Indian retail landscape over the last decade is reflected in the proliferation of supermarkets, departmental stores and hypermarkets in India. Evolving consumption patterns, raising living standards has sparked a huge demand in the food and grocery retailing. Impulse buying is a time-tested tactic by which retailers grab customer's attention and boost average purchase value. Prior research has deliberated extensively on impulse buying in the store and its determinants. However, little effort has been made to examine the impulse buying behaviour, particularly at the retail checkout. To bridge this gap, we conducted an empirical study in the leading food and grocery modern retail stores in selected Tier I and Tier II cities in the state of Karnataka, India. The data was collected from 385 respondents using a structured questionnaire. The responses were analysed using confirmatory factor analysis and multiple regression. Our study shows that impulse buying at the store checkout area is minimal and sporadic for most of the product categories at the checkout. Impulse buying at the checkout is instigated by factors such as store environment, credit card availability, momentary mood, in-store promotion, offers and discounts and large merchandise. The study has important implications for retail stores by emphasising on the choice of merchandise offered for sale at the checkout area. Further, the investigation reveals that Indian shoppers are health-conscious and cautious about their purchase at the checkout rather than being impulsive.
\end{abstract}

Keywords: impulse buying, grocery retailing, in-store promotion, situational factors, external factors, retail checkout.

JEL Classification: D91, L21, L81, M31.

\section{Introduction}

Indian retail industry is the fifth-largest in the world and is one of the most preferred, fast-growing global destination for retail space (FICCI, 2020; IBEF, 2019). The organised retailing share is anticipated to grab a market share of $22 \%$ by 2021 , while the share of organised grocery stores and departmental chain stores is expected to touch $18 \%$ during the same period (Suneera, 2019). The modern food and grocery retail in India largely comprise of supermarkets and hypermarkets formats and are fast expanding due to evolving consumer preferences (Sandoval \& Sawant, 2019). Most of the Indian department stores have shared checkout at the entrance/exit area of the store (Pataskar, 2011; Fatima, 2013, p. 44). The efficiency of the checkout was observed to be poor in western Maharashtra, a highly developed urban zone in India (Pataskar, 2011, p. 202).

Researchers in the past often attributed checkout as a compelling, unavoidable and common experience in retail service encounters (Maister, 1985; Taylor, 1994; Van Riel et al., 2012; Schimmel \& Bekker, 2013; Weiss \& Tucker, 2018; Ullal \& Hawaldar, 2018; Hawaldar et al., 2019). Waiting at the checkout area is usually alleged as an unproductive time that does not create any value for the customer (Nethravathi et al., 2020; Van Riel et al., 2012). The checkout lane is flanked by the attractive product displays having a low cost, high margin to stimulate impulse buying (Nathanson, 2013). From the store's perspective, waiting at the checkout is an opportunity to raise additional revenue (Weiss \& Tucker, 2018; Ullal et al., 2020).

Pugliese (1998) reported about $69 \%$ of the magazines bought as an impulse buy at the checkout counter and perceived as a "want" by the customers in the U.S. A drop in impulse buying of candies and magazines were observed in Quincy, Massachusetts when the customers availed selfcheckout over staffed counters (Vinish et al., 2021; Adams, 2006). Hilliard (2014) shared evidence of impulse buying

${ }^{*}$ Corresponding author. E-mail: thiqbal34@gmail.com 
of items such as beer, aerated soft drinks, candy bars, chips and ice-creams by the American citizens at the checkout aisles in the food retail stores. According to a study by Nielsen in 2012, the impulse potential can be increased by positioning items near the store entrance or exit (Hilliard, 2014). This argument is true in the case of Coca Cola where more than $70 \%$ of its sales are through impulse buying as stated by the CEO Mr Muhtar Kent (Vinish et al., 2020; Karmali, 2007). Placing confectionary items near the checkout was effective in attracting small kids who pester their parents for purchasing the same (Raju et al., 2015). Impulse goods at the checkout generate good margins without affecting sales of items displayed in other areas of the store due to its exclusive placement near the billing counter (Vinish et al., 2020; Eder, 2002; Iyer, 1989).

While impulse sales are a huge opportunity to boost overall profit, Ghosh et al. (2010) advocate that customers visiting the stores expect fast and efficient billing system, which could be a hindrance to impulse buying at the checkout. According to Bettman (1979), the amount of time available regulate the degree of information processed. Iyer (1989) suggests that in the absence of time pressure customers search for in-store queues and are more likely to make an unplanned purchase in the context of a grocery store. Beatty and Ferrell (1998) found a positive relationship between the time available and the prospect of making an impulse buy. However, we have not come across any convincing evidence to confirm the impact of the presence of time pressure (faster checkout) or absence of time pressure on impulse buying behaviour precisely at the checkout counter.

Prior work on impulse purchase was focused on antecedents such as personal characteristics like shopping enjoyment and impulse buying tendency (Beatty \& Ferrell, 1998; Weun et al., 1998; Sharma al., 2010), optimum stimulation level (Nethravathi et al., 2020; Sharma et al., 2010), product-specific conceptualization and involvement (Jones et al., 2003), and situational variables such as time and money available (Beatty \& Ferrell, 1998), pointof-purchase signboards (Peck \& Childers, 2006), product display (Ghani \& Kamal, 2010), point-of-purchase posters featuring discount information (Zhou \& Wong, 2003).

Store characteristics such as in-store atmosphere and customer's emotional state (Vinish et al., 2021; Sherman et al., 1997), lighting, music and social factors such as salespeople attire and approach, merchandise quality (Baker et al., 1994), pricing and store image (Wheatley \& Chiu, 1977), shopping satisfaction (Bitner, 1990) were found to influence store preferences, the volume of purchase made, time and money spent in the store. Tauber (1972) suggested the need for socialising and peer group attraction as the reasons for visiting the stores. Presence of social cues and service quality drive favourable attitude towards the store and shopping arousal (Hu \& Jasper, 2006). Mohan et al. (2013) explored the synergy among environmental factors, individual factors and impulse buying behaviour. Nonetheless, there exists limited research on the influence of the above factors on impulse buying behaviour at the retail checkout in the Indian context. Thus, this study aims to analyse the impulse purchase of merchandise displayed at the store's checkout area; assess the impact of situational factors and external stimuli on the impulse purchase of products displayed at the checkout.

\section{Literature review}

Retailers have well acknowledged the sales generated through impulse buying (Clover, 1950), and hence it gave rise to considerable research interest (cf. Stern, 1962; Kollat \& Willett, 1969; Rook, 1987; Peck \& Childers, 2006; Ali \& Hasnu, 2013). Stern (1962) refined the meaning of impulse buying and classified impulse buying mix as pure, reminder, suggestion and planned. Exposure to in-store stimuli such as POP displays, price-off sales promotions, coupons and sampling, in-store siting, on-shelf product placements and demonstrations can lead to impulse buying decisions significantly (Abratt \& Goodey, 1990). Kollat and Willett (1967) contend that in-store stimuli remind the customers of their present or future needs. Impulse purchase involves the minimal expenditure of resources like time, physical and mental effort, and money (Ullal et al., 2020; Stern, 1962). A study by Abratt and Goodey (1990) showed customers spend more money than intended, which is against the views of Kollat and Willet that "there is a strong tendency for actual expenditure to approximate spending intentions".

Raju et al. (2015) attributed higher impulse buying behaviour among customers in offline stores due to the gratification they derive through immediate possession or consumption. Prior knowledge about new products complemented by the desire for shopping pleasure and esteem boost impulse buying intention and thus leading to buying behaviour (Harmancioglu et al., 2009).

The determinants of impulse buying are classified as store attributes, customer characteristics, situational factors and product features (Raju et al., 2015). This study takes into consideration the impact of situational and external factors on impulse buying at the checkout area.

\subsection{Situational factors}

Belk (1975) described situations and recognised personal, environmental and social aspects of retail shopping as situational variables. Situational factors such as store environment, customer mood and impulsivity trait could determine the intensity of consumption impulse experienced (Dholakia, 2000). Substantial research within social psychology indicates positive mood state of customers enhance their sensation-seeking tendency and weaken the prospect of systematic information processing (see Schwarz \& Bohner, 1996). Mischel and Mischel (1983) claim that physical proximity could trigger positive memories associated with the product's consumption in the past and are likely to encourage the desire to buy. Park et al. (1989) explored the effect of situational factor "time available for shopping" on unplanned buying and 
found a positive relationship between the two. According to Beatty and Ferrell (1998) and Foroughi et al. (2014) time and money availability are important situational factors influencing the urge to buy impulsively and eventually making an impulse purchase. Innovations such as credit cards (Ullal et al., 2021; Omar \& Kent, 2001; Bhakat \& Muruganantham, 2013; Bhuvaneswari \& Krishnan, 2015), availability of online stores 24 hours a day (Pradhan, 2016) have induced impulse purchase.

Rook (1987) argued that perceived impulse buying intensity and the ability to control the impulses vary among customers. Kacen and Lee (2002) stated that independent customers are more impulse buying oriented as compared to dependent customers. "Highly impulsive buyers are more likely to experience spontaneous buying; their shopping lists are more "open" and receptive to sudden, unexpected buying ideas" (Rook \& Fisher, 1995, p. 306). Bell et al. (2011) point out the variation in pricing, variety, location and store ambience among retail formats could lead to disparity in in-store buying decisions. Pradhan (2016) examined the factors persuading impulse buying in Kathmandu supermarkets and found reference groups (family and friends) as one of the significant attributes triggering impulse purchase. Luo (2005) made a contrasting conclusion about the behaviour of customers where their urge to buy impulsively increased during the presence of peer customers while it decreased during the presence of family members. Based on the above discussion, we hypothesise:

$\mathrm{H}_{1}$ : Situational factors contribute positively to impulse buying at the retail checkout.

\subsection{External stimuli}

Applebaum (1951) was one of the early researchers who suggested in-store stimuli such as display, pricing, sales conversations and demonstrations as a catalyst for impulse purchase by the customers. Bhakat and Muruganantham (2013) mentioned lighting, layout, fixtures, colour, sound, odour, floor coverings and behaviour of staff influencing the retail store atmosphere. Youn and Faber (2000) described external stimuli as specific triggers connected with shopping and managed by marketers to entice customers to purchase action. It includes dealing with shopping environment (i.e. Store ambience, size, design and format) and marketing environments such as sales and advertising activities (Bhakat \& Muruganantham, 2013). Piron (1991) points to four dimensions of stimuli connected with impulse buying viz (1) response to marketing reminders or recommendations (Stern, 1962), (2) manipulation of store atmosphere (Kotler, 1974), POP display (see Shimp \& DeLozier, 1986) and product positioning (Berkman \& Gilson, 1986), (3) non-satisfactory or unavailable planned purchases (Iyer \& Ahlawat, 1987), and (4) customer-generated non-environmental persuaded stimulation.

Customers also face an urge to make an impulse purchase when confronted with visual inducements such as promotional offers (Ullal et al., 2021; Dholakia, 2000). Buying impulses essentially activate with individual's sensation and perception determined by external stimuli resulting in a sudden urge to buy (Rook \& Hoch, 1985). In large stores stimuli such as merchandise display, price, store environment and the large variety form the key motives for an impulse purchase (Gupta et al., 2009). While in small stores product price continued to be the prime factor for an impulse purchase. Yu and Bastin (2010) deliberated on the role of store employees in motivating and complementing customers, thus leading to impulse buying. Atulkar and Kesari (2018) and Husnain et al. (2019) mentioned that friendly employees play an important role in an impulse purchase. Badgaiyan and Verma (2015) reflected on family influence on impulse buying. Social interaction among customers and with their friends, relatives during the shopping mostly influence them to spend more time in the store and make impulse buying decisions (Baron et al., 1996). Lin and Chen (2012) concluded that impulse buying tendency tends to be higher when the susceptibility to interpersonal influence is more. Based on the above and in line with (Bhakat \& Muruganantham, 2013), we hypothesise:

$\mathrm{H}_{2}$ : External stimuli positively lead to impulse buying at the retail checkout.

\section{Methodology}

\subsection{Sample designing and data collection}

We have followed a single-stage mall intercept survey method to gather responses much like earlier studies (e.g.: Beatty \& Ferrell, 1998; Sharma et al., 2010; Mohan et al., 2013). The respondents include both resident and tourist customers the Indian state of Karnataka.

According to MSME-Development Institute (2016), Karnataka is the "one of the most progressive and industrialized states in the country and is leading States in driving India's economic growth". The state is popularly hailed as Silicon Valley of India with a population of more than 61 million with fourth highest FDI in the country (KPMG, 2018). The state recorded IT exports worth US\$ 77.80 billion in the year 2018-19 (IBEF, 2020), and is the 4th largest technology cluster in the world (IBEF, 2018). In terms of Human Development Index, the state shares the nineteenth rank (Global Data Lab, 2019) in the country. The NASSCOM-AT Kearney Report (2017) has identified four major cities in Karnataka viz. Bengaluru (leader location), Mangaluru (challenger location), HubballiDharwad and Mysuru (aspirant location) for its business potential. The study, therefore, considered a sample of 385 customers (convenience sampling method) visiting the leading retail stores such as two supermarkets namely Nilgiris and More, and two hypermarkets i.e. Big Bazaar and Spar in leading Tier I (Bengaluru) and Tier II (Mangaluru, Mysuru, Hubballi-Dharwad) cities in the state of Karnataka, India.

The stores selected for the study have Pan India presence offering a wide range of branded merchandise such as grocery, fruits and vegetables, bakery, meat, dairy 
products, poultry, personal care and plastics. Big Bazaar and Spar also offer larger products like textiles, electronics, IT products besides offering products sold in More and Nilgiris stores. Moreover, the stores have a unique layout, large product display, checkout layout and number of counters, choice of products, offers and discounts, trained staff and unique dress code, and are intended to encourage customers' emotions and purchase behaviour. The study explores the influence of situational and external factors on the impulse buying behaviour of customers, particularly at the store checkout area. The constructs and the scale items used in this study are borrowed from the literature study and modified to suit the present study.

\subsection{Convergent and discriminant validity}

Convergent and discriminant validities are two vital parts of construct validity. The discriminant validity depicts the construct that not only should correlate with related variables, but it also should not correlate with dissimilar and unrelated ones. Convergent validity illustrates by what means the new scale is related to other variables and other measures of the same construct (de Vet et al., 2011; Streiner et al., 2015). The study examines the concurrent validity of the respondents' impulse buying behaviour with situational and external factors, using convergent and discriminant analysis.

Table 1 shows the convergent validity of the situational factors with seven items. Convergent validity examines the strength of the variables.

From Table 1, it is observed that there exists a strong correlation between the variables of situational factors, with p-value $0.000<0.005$ at $1 \%$ significance level.

Table 2. Discriminant validity of situational factors

\begin{tabular}{|l|c|c|c|c|c|}
\hline & $\begin{array}{c}\text { Wilks' } \\
\text { Lambda }\end{array}$ & F & df1 & df2 & Sig. \\
\hline Money availability & .973 & 2.641 & 4 & 380 & .034 \\
\hline Time availability & .946 & 5.467 & 4 & 380 & .000 \\
\hline Family influence & .932 & 6.904 & 4 & 380 & .000 \\
\hline Social Influence & .921 & 8.125 & 4 & 380 & .000 \\
\hline Store environment & .857 & 15.916 & 4 & 380 & .000 \\
\hline $\begin{array}{l}\text { Credit card } \\
\text { availability }\end{array}$ & .830 & 19.398 & 4 & 380 & .000 \\
\hline Momentary Mood & .857 & 15.868 & 4 & 380 & .000 \\
\hline
\end{tabular}

Table 1. Correlation between the variables of situational factors

\begin{tabular}{|c|c|c|c|c|c|c|c|c|}
\hline & & $\begin{array}{c}\text { Money } \\
\text { availability }\end{array}$ & $\begin{array}{c}\text { Time } \\
\text { availability }\end{array}$ & $\begin{array}{l}\text { Family } \\
\text { influence }\end{array}$ & $\begin{array}{c}\text { Social } \\
\text { Influence }\end{array}$ & $\begin{array}{c}\text { Store } \\
\text { environment }\end{array}$ & $\begin{array}{l}\text { Credit card } \\
\text { availability }\end{array}$ & $\begin{array}{c}\text { Momentary } \\
\text { Mood }\end{array}$ \\
\hline \multirow{3}{*}{$\begin{array}{l}\text { Money } \\
\text { availability }\end{array}$} & \begin{tabular}{|l} 
Pearson \\
Correlation
\end{tabular} & 1 & $.424^{* *}$ & $.334^{* *}$ & $.299^{* *}$ & $.235^{* *}$ & $.169^{* *}$ & $.385^{* *}$ \\
\hline & Sig. (2-tailed) & & .000 & .000 & .000 & .000 & .001 & .000 \\
\hline & $\mathrm{N}$ & 385 & 385 & 385 & 385 & 385 & 385 & 385 \\
\hline \multirow{3}{*}{ Time availability } & $\begin{array}{l}\text { Pearson } \\
\text { Correlation }\end{array}$ & $.424^{* *}$ & 1 & $.244^{* *}$ & $.252^{* *}$ & $.320^{* *}$ & $.224^{* *}$ & $.329^{* *}$ \\
\hline & Sig. (2-tailed) & .000 & & .000 & .000 & .000 & .000 & .000 \\
\hline & $\mathrm{N}$ & 385 & 385 & 385 & 385 & 385 & 385 & 385 \\
\hline \multirow{3}{*}{ Family influence } & $\begin{array}{l}\text { Pearson } \\
\text { Correlation }\end{array}$ & $.334^{* *}$ & $.244^{* *}$ & 1 & $.472^{* *}$ & $.184^{* *}$ & $.245^{* *}$ & $.187^{* *}$ \\
\hline & Sig. (2-tailed) & .000 & .000 & & .000 & .000 & .000 & .000 \\
\hline & $\mathrm{N}$ & 385 & 385 & 385 & 385 & 385 & 385 & 385 \\
\hline \multirow{3}{*}{ Social Influence } & $\begin{array}{l}\text { Pearson } \\
\text { Correlation }\end{array}$ & $.299^{* *}$ & $.252^{* *}$ & $.472^{* *}$ & 1 & $.277^{* *}$ & $.335^{* *}$ & $.325^{* *}$ \\
\hline & Sig. (2-tailed) & .000 & .000 & .000 & & .000 & .000 & .000 \\
\hline & $\mathrm{N}$ & 385 & 385 & 385 & 385 & 385 & 385 & 385 \\
\hline \multirow{3}{*}{$\begin{array}{l}\text { Store } \\
\text { environment }\end{array}$} & $\begin{array}{l}\text { Pearson } \\
\text { Correlation }\end{array}$ & $.235^{* *}$ & $.320^{* *}$ & $.184^{* *}$ & $.277^{* *}$ & 1 & $.403^{* *}$ & $.311^{* *}$ \\
\hline & Sig. (2-tailed) & .000 & .000 & .000 & .000 & & .000 & .000 \\
\hline & $\mathrm{N}$ & 385 & 385 & 385 & 385 & 385 & 385 & 385 \\
\hline \multirow{3}{*}{$\begin{array}{l}\text { Credit card } \\
\text { availability }\end{array}$} & \begin{tabular}{|l|} 
Pearson \\
Correlation
\end{tabular} & $.169^{* *}$ & $.224^{* *}$ & $.245^{* *}$ & $.335^{* *}$ & $.403^{* *}$ & 1 & $.269^{* *}$ \\
\hline & Sig. (2-tailed) & .001 & .000 & .000 & .000 & .000 & & .000 \\
\hline & $\mathrm{N}$ & 385 & 385 & 385 & 385 & 385 & 385 & 385 \\
\hline \multirow{3}{*}{$\begin{array}{l}\text { Momentary } \\
\text { Mood }\end{array}$} & $\begin{array}{l}\text { Pearson } \\
\text { Correlation }\end{array}$ & $.385^{* *}$ & $.329^{* *}$ & $.187^{* *}$ & $.325^{* *}$ & $.311^{* *}$ & $.269^{* *}$ & 1 \\
\hline & Sig. (2-tailed) & .000 & .000 & .000 & .000 & .000 & .000 & \\
\hline & $\mathrm{N}$ & 385 & 385 & 385 & 385 & 385 & 385 & 385 \\
\hline
\end{tabular}

${ }_{* *}$ Correlation is significant at the 0.01 level (2-tailed). 
Table 2 presents that the independent variables of situational factors are significant at $0.000<0.005$. Hence, the discriminant dimensions are highly significant and show a strong relationship.

Table 3 interprets the convergent validity of external factors with eight items. The strength of the variables is measured through convergent validity.

Table 3 shows a strong correlation between the variables of external factors, with p-value $0.000<0.005$ at $1 \%$ significance level.

Table 4 shows that the independent variables of external factors are significant at $0.000<0.005$. Hence, the discriminant dimensions are highly significant and show a strong relationship.
Table 4. Discriminant validity of external factors

\begin{tabular}{|l|c|c|c|c|c|}
\hline & $\begin{array}{c}\text { Wilks' } \\
\text { Lambda }\end{array}$ & F & df1 & df2 & Sig. \\
\hline In-store promotion & .914 & 8.897 & 4 & 380 & .000 \\
\hline Offers and discounts & .946 & 5.439 & 4 & 380 & .000 \\
\hline Bonus Packs & .899 & 10.658 & 4 & 380 & .000 \\
\hline Large merchandise & .898 & 10.823 & 4 & 380 & .000 \\
\hline Product placement & .908 & 9.590 & 4 & 380 & .000 \\
\hline Peer influence & .924 & 7.822 & 4 & 380 & .000 \\
\hline In-store service & .919 & 8.399 & 4 & 380 & .000 \\
\hline Friendly employees & .944 & 5.609 & 4 & 380 & .000 \\
\hline
\end{tabular}

Table 3. Correlation between the variables of external factors

\begin{tabular}{|c|c|c|c|c|c|c|c|c|c|}
\hline & & \begin{tabular}{|c|} 
In-store \\
promotion
\end{tabular} & $\begin{array}{l}\text { Offers \& } \\
\text { discounts }\end{array}$ & $\begin{array}{l}\text { Bonus } \\
\text { Packs }\end{array}$ & $\begin{array}{c}\text { Large } \\
\text { merchandise }\end{array}$ & $\begin{array}{c}\text { Product } \\
\text { placement }\end{array}$ & $\begin{array}{c}\text { Peer } \\
\text { influence }\end{array}$ & $\begin{array}{l}\text { In-store } \\
\text { service }\end{array}$ & $\begin{array}{c}\text { Friendly } \\
\text { employees }\end{array}$ \\
\hline \multirow{3}{*}{$\begin{array}{l}\text { In-store } \\
\text { pro- } \\
\text { motion }\end{array}$} & $\begin{array}{l}\text { Pearson } \\
\text { Correlation }\end{array}$ & 1 & $.499^{* *}$ & $.450^{* *}$ & $.228^{* *}$ & $.334^{* *}$ & $.377^{* *}$ & $.247^{* *}$ & $.276^{* *}$ \\
\hline & Sig. (2-tailed) & & .000 & .000 & .000 & .000 & .000 & .000 & .000 \\
\hline & $\mathrm{N}$ & 385 & 385 & 385 & 385 & 385 & 385 & 385 & 385 \\
\hline \multirow{3}{*}{$\begin{array}{l}\text { Offers } \\
\text { and dis- } \\
\text { counts }\end{array}$} & $\begin{array}{l}\text { Pearson } \\
\text { Correlation }\end{array}$ & $.499^{* *}$ & 1 & $.680^{* *}$ & $.378^{* *}$ & $.357^{* *}$ & $.449^{* *}$ & $.325^{* *}$ & $.376^{* *}$ \\
\hline & Sig. (2-tailed) & .000 & & .000 & .000 & .000 & .000 & .000 & .000 \\
\hline & $\mathrm{N}$ & 385 & 385 & 385 & 385 & 385 & 385 & 385 & 385 \\
\hline \multirow{3}{*}{$\begin{array}{l}\text { Bonus } \\
\text { Packs }\end{array}$} & $\begin{array}{l}\text { Pearson } \\
\text { Correlation }\end{array}$ & $.450^{* *}$ & $.680^{* *}$ & 1 & $.470^{* *}$ & $.369^{* *}$ & $.480^{* *}$ & $.302^{* *}$ & $.367^{* *}$ \\
\hline & Sig. (2-tailed) & .000 & .000 & & .000 & .000 & .000 & .000 & .000 \\
\hline & $\mathrm{N}$ & 385 & 385 & 385 & 385 & 385 & 385 & 385 & 385 \\
\hline \multirow{3}{*}{$\begin{array}{l}\text { Large } \\
\text { mer- } \\
\text { chandise }\end{array}$} & $\begin{array}{l}\text { Pearson } \\
\text { Correlation }\end{array}$ & $.228^{* *}$ & $.378^{* *}$ & $.470^{* *}$ & 1 & $.494^{* *}$ & $.397^{* *}$ & $.499^{* *}$ & $.435^{* *}$ \\
\hline & Sig. (2-tailed) & .000 & .000 & .000 & & .000 & .000 & .000 & .000 \\
\hline & $\mathrm{N}$ & 385 & 385 & 385 & 385 & 385 & 385 & 385 & 385 \\
\hline \multirow{3}{*}{$\begin{array}{l}\text { Product } \\
\text { place- } \\
\text { ment }\end{array}$} & \begin{tabular}{|l} 
Pearson \\
Correlation
\end{tabular} & $.334^{* *}$ & $.357^{* *}$ & $.369^{* *}$ & $.494^{* *}$ & 1 & $.558^{* *}$ & $.447^{* *}$ & $.428^{* *}$ \\
\hline & Sig. (2-tailed) & .000 & .000 & .000 & .000 & & .000 & .000 & .000 \\
\hline & $\mathrm{N}$ & 385 & 385 & 385 & 385 & 385 & 385 & 385 & 385 \\
\hline \multirow{3}{*}{$\begin{array}{l}\text { Peer } \\
\text { influ- } \\
\text { ence }\end{array}$} & $\begin{array}{l}\text { Pearson } \\
\text { Correlation }\end{array}$ & $.377^{* *}$ & $.449^{* *}$ & $.480^{* *}$ & $.397^{* *}$ & $.558^{* *}$ & 1 & $.487^{* *}$ & $.421^{* *}$ \\
\hline & Sig. (2-tailed) & .000 & .000 & .000 & .000 & .000 & & .000 & .000 \\
\hline & $\mathrm{N}$ & 385 & 385 & 385 & 385 & 385 & 385 & 385 & 385 \\
\hline \multirow{3}{*}{$\begin{array}{l}\text { In-store } \\
\text { service }\end{array}$} & $\begin{array}{l}\text { Pearson } \\
\text { Correlation }\end{array}$ & $.247^{* *}$ & $.325^{* *}$ & $.302^{* *}$ & $.499^{* *}$ & $.447^{* *}$ & $.487^{* *}$ & 1 & $.765^{* *}$ \\
\hline & Sig. (2-tailed) & .000 & .000 & .000 & .000 & .000 & .000 & & .000 \\
\hline & $\mathrm{N}$ & 385 & 385 & 385 & 385 & 385 & 385 & 385 & 385 \\
\hline \multirow{3}{*}{$\begin{array}{l}\text { Friendly } \\
\text { emp- } \\
\text { loyees }\end{array}$} & $\begin{array}{l}\text { Pearson } \\
\text { Correlation }\end{array}$ & $.276^{* *}$ & $.376^{* *}$ & $.367^{* *}$ & $.435^{* *}$ & $.428^{* *}$ & $.421^{\star *}$ & $.765^{* *}$ & 1 \\
\hline & Sig. (2-tailed) & .000 & .000 & .000 & .000 & .000 & .000 & .000 & \\
\hline & $\mathrm{N}$ & 385 & 385 & 385 & 385 & 385 & 385 & 385 & 385 \\
\hline
\end{tabular}

** Correlation is significant at the 0.01 level (2-tailed). 


\subsection{Reliability statistics for the impact of various factors on impulse buying behaviour at the retail checkout}

The effect of various factors on impulse buying behaviour among the respondents is measured through 15 variables derived from the literature using a five-point Likert scale.

Table 5. Reliability statistics

\begin{tabular}{|c|c|c|}
\hline $\begin{array}{c}\text { Cronbach's } \\
\text { Alpha }\end{array}$ & $\begin{array}{c}\text { Cronbach's Alpha Based } \\
\text { on Standardized Items }\end{array}$ & N of Items \\
\hline 0.863 & 0.865 & 15 \\
\hline
\end{tabular}

The calculated Cronbach's Alpha of 0.865 (refer Table 5) indicates that there is a very high level of internal consistency for 15 items defined, which intern concludes the scale used to measure factors on impulse buying is behaviour is highly reliable.

\section{Data analysis and findings}

\subsection{Demographic profile}

The sample consists of $36.1 \%$ of the respondents belonging to the age group of $31-40$ years, $35.8 \%$ of the respondents from the category $21-30$ years, $22.3 \%$ of the respondents belong to $41-50$ years, $4.7 \%$ of the respondents belong to $>50$ years and $1 \%$ of the respondents below 20 years. Majority of the respondents are women $(54.5 \%)$ followed by men (45.5\%). $61.6 \%$ of the respondents are married, while $37.4 \%$ are unmarried, $1 \%$ is widowed and none are divorced. Most of the respondents (35.8\%) visited More supermarket, $26.8 \%$ visited Spar hypermarket, 26\% visited Big Bazaar Supermarket and $11.4 \%$ visited Nilgiris supermarket. $37.7 \%$ of the respondents predominantly visited the store weekly, 33.8\% visited monthly, 9.9\% visited occasionally and few (3.1\%) visited bi-monthly. Table 6 provides an analysis of the data obtained from the survey.

\subsection{Factor analysis of the variables influencing impulse buying behaviour}

Factor analysis is conducted to describe the variability among observed, correlated variables into a potentially lower number of unobserved variables.

Kaiser-Meyer-Olkin $(\mathrm{KMO})=0.823>0.50($ refer Table 7), indicates that the sample size is sufficient to conduct factor analysis.
Table 6. Demographic profile

\begin{tabular}{|c|c|c|c|}
\hline & & Count & Percentage \\
\hline \multirow{6}{*}{ Age } & $<20$ years & 4 & $1.00 \%$ \\
\hline & $21-30$ years & 138 & $35.80 \%$ \\
\hline & $31-40$ years & 139 & $36.10 \%$ \\
\hline & $41-50$ years & 86 & $22.30 \%$ \\
\hline & $>50$ years & 18 & $4.70 \%$ \\
\hline & Total & 385 & $100.00 \%$ \\
\hline \multirow{3}{*}{ Gender } & Male & 175 & $45.50 \%$ \\
\hline & Female & 210 & $54.50 \%$ \\
\hline & Total & 385 & $100.00 \%$ \\
\hline \multirow{5}{*}{$\begin{array}{l}\text { Marital } \\
\text { Status }\end{array}$} & Single & 144 & $37.40 \%$ \\
\hline & Married & 237 & $61.60 \%$ \\
\hline & Divorced & 0 & $0.00 \%$ \\
\hline & Widowed & 4 & $1.00 \%$ \\
\hline & Total & 385 & $100.00 \%$ \\
\hline \multirow{5}{*}{$\begin{array}{l}\text { Store } \\
\text { visited }\end{array}$} & More Supermarket & 138 & $35.80 \%$ \\
\hline & $\begin{array}{l}\text { Nilgiris } \\
\text { Supermarket }\end{array}$ & 44 & $11.40 \%$ \\
\hline & $\begin{array}{l}\text { Big Bazaar } \\
\text { Hypermarket }\end{array}$ & 100 & $26.00 \%$ \\
\hline & Spar Hypermarket & 103 & $26.80 \%$ \\
\hline & Total & 385 & $100.00 \%$ \\
\hline \multirow{6}{*}{$\begin{array}{l}\text { Frequency } \\
\text { of visit }\end{array}$} & Weekly & 145 & $37.70 \%$ \\
\hline & Fortnightly & 60 & $15.60 \%$ \\
\hline & Monthly & 130 & $33.80 \%$ \\
\hline & Bi-monthly & 12 & $3.10 \%$ \\
\hline & Occasionally & 38 & $9.90 \%$ \\
\hline & Total & 385 & $100.00 \%$ \\
\hline
\end{tabular}

Table 7. KMO and Bartlett's test

\begin{tabular}{|c|c|c|}
\hline \multicolumn{2}{|c|}{$\begin{array}{l}\text { Kaiser-Meyer-Olkin Measure of Sampling } \\
\text { Adequacy }\end{array}$} & 0.823 \\
\hline \multirow{3}{*}{$\begin{array}{l}\text { Bartlett's Test of } \\
\text { Sphericity }\end{array}$} & Approx. Chi-Square & 2150.057 \\
\hline & Df & 105 \\
\hline & Sig. & 0.000 \\
\hline
\end{tabular}

The Bartlett's test p-value is $0.000<0.05$, therefore there exists a correlation between variables and thus factor analysis can be carried out.

Table 8 represents that the first factor accounts for $35.35 \%$ of the variance. The second factor accounts for $10.62 \%$ of the variance. All the remaining factors are not significant.

Table 8. Total variance explained

\begin{tabular}{|c|c|c|c|c|c|c|c|c|c|}
\hline \multirow{2}{*}{$\begin{array}{c}\text { Com- } \\
\text { ponent }\end{array}$} & \multicolumn{4}{|c|}{ Initial Eigenvalues } & \multicolumn{2}{|c|}{ Extraction Sums of Squared Loadings } & \multicolumn{2}{c|}{ Rotation Sums of Squared Loadings } \\
\cline { 2 - 10 } & Total & $\begin{array}{c}\% \text { of } \\
\text { Variance }\end{array}$ & $\begin{array}{c}\text { Cumulative } \\
\%\end{array}$ & Total & $\begin{array}{c}\% \text { of } \\
\text { Variance }\end{array}$ & $\begin{array}{c}\text { Cumulative } \\
\%\end{array}$ & Total & $\begin{array}{c}\% \text { of } \\
\text { Variance }\end{array}$ & $\begin{array}{c}\text { Cumulative } \\
\%\end{array}$ \\
\hline 1 & 5.303 & 35.353 & 35.353 & 5.303 & 35.353 & 35.353 & 4.082 & 27.212 & 27.212 \\
\hline 2 & 1.594 & 10.628 & 45.980 & 1.594 & 10.628 & 45.980 & 2.815 & 18.768 & 45.980 \\
\hline
\end{tabular}


The variables are loaded into two factors. Table 9 presents the same.

Table 9. Factor loadings for the influencing factors

\begin{tabular}{|c|c|c|c|c|}
\hline Factor & Items included & $\begin{array}{c}\text { Rotated } \\
\text { Component } \\
\text { matrix }\end{array}$ & $\begin{array}{l}\text { Name } \\
\text { of the } \\
\text { factor }\end{array}$ & $\begin{array}{c}\text { Percentage } \\
\text { Contri- } \\
\text { bution }\end{array}$ \\
\hline \multirow{8}{*}{ Factor 1} & $\begin{array}{l}\text { Friendly } \\
\text { employees }\end{array}$ & 0.742 & \multirow{8}{*}{$\begin{array}{l}\text { External } \\
\text { factors }\end{array}$} & \multirow{8}{*}{$35.35 \%$} \\
\hline & $\begin{array}{l}\text { In-store } \\
\text { service }\end{array}$ & 0.737 & & \\
\hline & Peer influence & 0.698 & & \\
\hline & $\begin{array}{l}\text { Offers and } \\
\text { discounts }\end{array}$ & 0.697 & & \\
\hline & Bonus Packs & 0.694 & & \\
\hline & $\begin{array}{l}\text { Large } \\
\text { merchandise }\end{array}$ & 0.687 & & \\
\hline & $\begin{array}{l}\text { Product } \\
\text { placement }\end{array}$ & 0.640 & & \\
\hline & $\begin{array}{l}\text { In-store } \\
\text { promotion }\end{array}$ & 0.509 & & \\
\hline \multirow{7}{*}{ Factor 2} & $\begin{array}{l}\text { Time } \\
\text { availability }\end{array}$ & 0.709 & \multirow{7}{*}{$\begin{array}{l}\text { Situa- } \\
\text { tional } \\
\text { factors }\end{array}$} & \multirow{7}{*}{$10.62 \%$} \\
\hline & $\begin{array}{l}\text { Family } \\
\text { influence }\end{array}$ & 0.642 & & \\
\hline & $\begin{array}{l}\text { Money } \\
\text { availability }\end{array}$ & 0.638 & & \\
\hline & $\begin{array}{l}\text { Social } \\
\text { Influence }\end{array}$ & 0.619 & & \\
\hline & $\begin{array}{l}\text { Momentary } \\
\text { Mood }\end{array}$ & 0.592 & & \\
\hline & $\begin{array}{l}\text { Credit card } \\
\text { availability }\end{array}$ & 0.474 & & \\
\hline & \begin{tabular}{|l|}
$\begin{array}{l}\text { Store } \\
\text { environment }\end{array}$ \\
\end{tabular} & 0.468 & & \\
\hline
\end{tabular}

The antecedents of impulse buying are classified into external and situational factors. Among the two, the external factors emerged to be the leading determinant of impulse buying behaviour at the retail checkout with the factor loading $35.35 \%$. Also, variables such as "friendly employees" and "in-store service" under external factors are found to highly influence the impulse buying behaviour. Whereas in situational factors, "time availability" is found to have highest bearing on the impulse buying behaviour.

\subsection{Impact of situational and external factors on impulse buying behaviour}

Multiple regression analysis was performed by considering seven and eight factors concerning situational factors and external factors as independent variables and impulse buying behaviour "Make a spontaneous purchase at the checkout area" as the dependent variable.

$\mathrm{H}_{1}$ : Situational factors contribute positively to impulse buying at the retail checkout.
Table 10. Influence of situational factors on impulse buying

\begin{tabular}{|c|l|c|c|c|c|c|}
\hline \multirow{2}{*}{$\begin{array}{c}\text { SL. } \\
\text { NO }\end{array}$} & $\begin{array}{c}\text { Inde- } \\
\text { pendent } \\
\text { Variables }\end{array}$ & \multicolumn{2}{|c|}{$\begin{array}{c}\text { Unstandardized } \\
\text { Coefficients }\end{array}$} & $\begin{array}{c}\text { Standar- } \\
\text { dized } \\
\text { Coeffi- } \\
\text { cients }\end{array}$ & T & Sig. \\
\cline { 2 - 5 } & & B & $\begin{array}{c}\text { Std. } \\
\text { Error }\end{array}$ & Beta & & \\
\hline 1 & $\begin{array}{l}\text { (Constant) } \\
\text { Money } \\
\text { availability }\end{array}$ & 0.183 & -0.323 & & 0.567 & 0.571 \\
\hline 2 & $\begin{array}{l}\text { Time } \\
\text { availability }\end{array}$ & -0.003 & 0.070 & -0.002 & -0.036 & 0.971 \\
\hline 3 & $\begin{array}{l}\text { Family in- } \\
\text { fluence }\end{array}$ & 0.054 & 0.066 & 0.043 & 0.827 & 0.409 \\
\hline 4 & $\begin{array}{l}\text { Social in- } \\
\text { fluence }\end{array}$ & 0.085 & 0.062 & 0.074 & 1.371 & 0.171 \\
\hline 5 & $\begin{array}{l}\text { Store en- } \\
\text { vironment }\end{array}$ & 0.197 & 0.062 & 0.162 & 3.170 & $0.002^{*}$ \\
\hline 6 & $\begin{array}{l}\text { Credit } \\
\text { card avail- } \\
\text { ability }\end{array}$ & 0.215 & 0.048 & 0.225 & 4.439 & $0.000^{\star *}$ \\
\hline 7 & $\begin{array}{l}\text { Momen- } \\
\text { tary Mood }\end{array}$ & 0.318 & 0.063 & 0.257 & 5.008 & $0.000^{\star *}$ \\
\hline $\begin{array}{l}\text { A. Dependent Variable: Make a spontaneous purchase at the } \\
\text { checkout area }\end{array}$ & & & & \\
\hline
\end{tabular}

Note: Significant at: ${ }^{\star} 0.05,{ }^{\star *} 0.01$ levels.

Table 11. Model summary

\begin{tabular}{|c|c|c|c|}
\hline$R$ & R Square & Adjusted R Square & P-value \\
\hline 0.507 & 0.257 & 0.244 & $0.000^{\star *}$ \\
\hline
\end{tabular}

Table 10 provides the standardised beta coefficients and $\mathrm{p}$-value for the factors causing impulse buying behaviour. The result shows that among the seven factors, three factors were statistically significant, with a $\mathrm{p}$-value less than 0.05 . They are (1) "Store environment" $(\beta=$ $0.162, p=0.002),(2)$ "Credit card availability" $(\beta=0.225$, $\mathrm{p}=0.000)$ and (3) "Momentary Mood" $(\beta=0.257, \mathrm{p}=$ $0.000)$. Other factors have a low impact on impulse buying behaviour. However, they are not statistically significant.

Table 11 gives the adjusted $\mathrm{R}$ square value for impulse buying behaviour. The overall impact of these factors on the level of impulse buying was $24.4 \%$. So, the hypothesis $\mathrm{H}_{1}$ is accepted.

$\mathrm{H}_{2}$ : External stimuli positively lead to impulse buying at the retail checkout.

Table 12 provides the standardised beta coefficients and $\mathrm{p}$-value for the factors causing impulse buying behaviour. The result shows that among the eight factors, three factors were statistically significant, with a p-value less than 0.05 . They are (1) "In-store promotion" $(\beta=0.123, p$ $=0.032),(2)$ "Offers and discounts" $(\beta=0.142, \mathrm{p}=0.041)$ and (3) "Large merchandise" $(\beta=0.152, p=0.016)$. Other factors have a low impact on impulse buying behaviour. However, they are not statistically significant. 
Table 12. Influence of external factors on impulse buying

\begin{tabular}{|c|c|c|c|c|c|c|}
\hline \multirow{2}{*}{$\begin{array}{c}\text { Sl } \\
\text { No }\end{array}$} & \multirow{2}{*}{$\begin{array}{c}\text { Independent } \\
\text { Variables }\end{array}$} & \multicolumn{2}{|c|}{$\begin{array}{l}\text { Unstan- } \\
\text { dardized } \\
\text { Coefficients }\end{array}$} & \multirow{2}{*}{$\begin{array}{c}\begin{array}{c}\text { Stan- } \\
\text { dar- } \\
\text { dized } \\
\text { Coeffi- } \\
\text { cients }\end{array} \\
\text { Beta }\end{array}$} & \multirow{2}{*}{$\mathrm{t}$} & \multirow{2}{*}{ Sig. } \\
\hline & & B & $\begin{array}{l}\text { Std. } \\
\text { Error }\end{array}$ & & & \\
\hline & (Constant) & 0.835 & 0.327 & & 2.554 & 0.011 \\
\hline 1 & $\begin{array}{l}\text { In-store pro- } \\
\text { motion }\end{array}$ & 0.144 & 0.067 & 0.123 & 2.154 & $0.032^{\star}$ \\
\hline 2 & $\begin{array}{l}\text { Offers and } \\
\text { discounts }\end{array}$ & 0.191 & 0.093 & 0.142 & 2.047 & $0.041^{\star}$ \\
\hline 3 & Bonus Packs & 0.168 & 0.094 & 0.128 & 1.794 & 0.074 \\
\hline 4 & $\begin{array}{l}\text { Large mer- } \\
\text { chandise }\end{array}$ & 0.183 & 0.075 & 0.152 & 2.429 & $0.016^{*}$ \\
\hline 5 & $\begin{array}{l}\text { Product place- } \\
\text { ment }\end{array}$ & 0.076 & 0.084 & 0.057 & 0.909 & 0.364 \\
\hline 6 & Peer influence & 0.109 & 0.080 & 0.089 & 1.368 & 0.172 \\
\hline 7 & In-store service & 0.086 & 0.100 & 0.069 & 0.859 & 0.391 \\
\hline 8 & $\begin{array}{l}\text { Friendly } \\
\text { employees }\end{array}$ & 0.026 & 0.091 & 0.022 & 0.285 & 0.776 \\
\hline
\end{tabular}

Note: Significant at: ${ }^{\star} 0.05,{ }^{\star \star} 0.01$ levels.

Table 13. Model summary

\begin{tabular}{|c|c|c|c|}
\hline$R$ & R Square & Adjusted R Square & P-Value \\
\hline 0.378 & 0.143 & 0.125 & $0.000^{* *}$ \\
\hline
\end{tabular}

Table 13 gives the adjusted $\mathrm{R}$ square value for impulse buying behaviour. The overall impact of these factors on the level of impulse buying was $12.5 \%$. So, the hypothesis $\mathrm{H}_{2}$ is accepted.

\section{Managerial implications}

Retail checkout significantly influences the overall evaluation of customer store service and shopping experience. This study reveals some important findings on impulse buying at the retail checkout area. First, not all the product categories at the checkout area receive the same attention and urge to buy impulsively. The results of the study indicate that chocolates and personal care products are often bought by the customers impulsively, while other product categories such as ready to eat foods, Tobacco products, soft drinks, batteries, kitchen accessories, sports goods, stationery items and toys are rarely bought items. Moreover, the shoppers are found to be health-conscious by avoiding frequent purchases of tobacco products, soft drinks, ready to eat foods and chocolates. The results also suggest that store managers need to carefully plan the visual merchandising of the above product categories at the checkout area to gain the attention of more buyers and pursue them to impulse purchase.
Second, the regression analysis of situational construct suggests that Indian shoppers are influenced by store environment, momentary mood, and credit card availability. Yoo et al. (1998) and Cottet et al. (2010) showed that factors such as store design, lighting, colour, air quality, music and decoration contribute to the pleasant mood which in turn lead to impulse purchase behaviour. Credit card companies encourage customers to shop more and earn rewards. The increased usage of the credit cards by customers aids the retailers to boost their revenue through impulse sales. Retail stores should focus on cobranding their stores with leading credit card companies as a sales strategy.

Third, the in-store promotion, attractive offers and discounts, and large merchandise have emerged to be leading contributors to impulse buying under the external factors. Indian Retailers continues to woo shoppers by offering mouth-watering deals. This has heightened the shoppers' tendency to actively seek offers and discounts at every point of purchase. Thus, last-minute sales can be achieved by keeping the prices low, offering cashback and deep discounts. Online players such as Amazon and Flipkart have been undercutting the prices to drive traffic to their websites. To stay competitive, offline retailers need to consistently offer quality in-store service besides keeping the prices low.

Though situational factors like money and time availability, family and social influence are important antecedents of impulse buying behaviour inside the store, our study shows that these variables do not contribute to impulse buying at the retail checkout in specific. This reflects weak impulse buying at the checkout, which is reflected in the purchase of two product categories out of ten categories available. Similarly, external factors such as bonus packs, product placement, peer influence, in-store service, and friendly employees did not facilitate impulse buying at the checkout. During the survey, it was observed that the checkout area in the above stores is generally crowded and the shoppers were in a hurry to exit the billing counter. The customers were also busily engaged in observing the queue movement, and the other lines at the checkout, which validates Maister (1985) propositions about the "The Psychology of waiting lines". The interaction between customers and employees were minimal at the checkout area, as the billing staff were busy at their work and other store staffs were present near the aisles managing the inventory. This also could have affected the impulse buying at the checkout in specific.

\section{Conclusions}

Preceding studies on impulse buying in retail stores is deeply ingrained in the western community and developed economies, while in developing countries is limited. Moreover, the literature on impulse buying particularly at the checkout area is very limited. The results of the study will broaden the scope of impulse buying literature in India and other developing nations. Our study shows that 
impulse buying at the retail checkout is weak. Although the prior research identified important determinants of impulse buying in the store, our study shows that the Indian consumers are price and value-conscious and less impulsive while waiting in the queue at the checkout area. The customers often make healthy product choices at the checkout and are more focused on queue rather than on the retail shelves at the checkout area. Researchers have argued in the past that the comparison of factors significant to impulse buying behaviour is limited. While the situational and external factors have a bearing on the impulse buying behaviour at the checkout, our study hasn't considered the impact of impulse buying tendency. Further investigation could include this and bring out an integral model on impulse buying behaviour.

\section{Author contributions}

Below are the authors' contributions to this study:

- Vinish P wrote the first draft of the article, validated the research methodology, prepared the questionnaires, collected data, interpretated the result and wrote the final manuscript.

- Prakash Pinto validated the research methodology, collected data, supervised the data analysis and interpretation, revised the manuscript.

- Iqbal Thonse Hawaldar supervised and validated the results and discussions and the final manuscript preparation.

- Slima Pinto collected data, conducted data analyses, and interpreted the result.

\section{Disclosure statement}

The authors do not have any conflict of interest.

\section{References}

Abratt, R., \& Goodey, S. D. (1990). Unplanned buying and instore stimuli in supermarkets. Wiley, 11(2), 111-121. https://doi.org/10.1002/mde.4090110204

Adams, S. (2006, August 2). Self-checkouts up; impulse buys down; Stores see large drop in purchases of items such as candy, magazines. The Patriot Ledger, 17. https://search.proquest.com/docview/242732536/A7F3EFDAFF2C4CE6PQ/9? accountid $=193930$

Ali, A., \& Hasnu, S. (2013). An analysis of in-store shopping environment on consumers' impulse buying: evidence from Pakistan. Interdisciplinary Journal of Contemporary Research in Business, 5(2), 560-570.

Applebaum, W. (1951). Studying customer behavior in retail stores. Journal of Marketing, 16(2), 172-178. https://doi.org/10.1177/002224295101600204

Atulkar, S., \& Kesari, B. (2018). Role of consumer traits and situational factors on impulse buying: does gender matter? International Journal of Retail and Distribution Management, 46(4), 386-405. https://doi.org/10.1108/IJRDM-12-2016-0239

Badgaiyan, A. J., \& Verma, A. (2015). Does urge to buy impulsively differ from impulsive buying behaviour? Assessing the impact of situational factors. Journal of Retailing and Con- sumer Services, 22, 145-157.

https://doi.org/10.1016/j.jretconser.2014.10.002

Baker, J., Grewal, D., \& Parasuraman, A. (1994). The influence of store environment on quality inferences and store image. Journal of the Academy of Marketing Science, 22(4), 328-339. https://doi.org/10.1177/0092070394224002

Baron, S., Harris, K., \& Davies, B. J. (1996). Oral participation in retail service delivery: a comparison of the roles of contact personnel and customers. European Journal of Marketing, 30(9), 75-90. https://doi.org/10.1108/03090569610130052

Beatty, S. E., \& Elizabeth Ferrell, M. (1998). Impulse buying: Modeling its precursors. Journal of Retailing, 74(2), 169-191. https://doi.org/10.1016/S0022-4359(99)80092-X

Belk, R. W. (1975). Situational variables and consumer behavior. Journal of Consumer Research, 2(3), 157-164. https://doi.org/10.1086/208627

Bell, D. R., Corsten, D., \& Knox, G. (2011). From point of purchase to path to purchase: how preshopping factors drive unplanned buying. Journal of Marketing, 75(1), 31-45. https://doi.org/10.1509/jm.75.1.31

Berkman, H. W., \& Gilson, C. C. (1986). Consumer behavior: concepts and strategies (3rd ed.). Kent Pub. Co.

Bettman, J. R. (1979). Memory factors in consumer choice: a review. Journal of Marketing, 43(2), 37. https://doi.org/10.2307/1250740

Bhakat, R. S., \& Muruganantham, G. (2013). A review of impulse buying behavior. International Journal of Marketing Studies, 5(3), 149-160. https://doi.org/10.5539/ijms.v5n3p149

Bhuvaneswari, V., \& Krishnan, J. (2015). A review of literature on impulse buying behaviour of consumers in Brick \& Mortar and Click only stores. International Journal of Management Research and Social Science, 2(3), 84-90.

Bitner, M. (1990). Evaluating service encounters: the effects of physical surroundings and employee responses. Journal of Marketing, 54(2), 69-82. https://doi.org/10.1177/002224299005400206

Clover, V. T. (1950). Relative importance of impulse-buying in retail stores. Journal of Marketing, 15(1), 66-70. https://doi.org/10.2307/1247083

Cottet, P., Lichtle, M.-C., \& Plichon, V. (2010, June). The influence of ambient factors in services: the compared effects of perceived colors and store layout. In The 11th International Research Seminar in Service Managemen (pp. 1-24). http://www.lalondeconference.com/SM/2010_lalonde_seminar/papers/p08-112-cottet-plichon-lichtlerev25032010.pdf

de Vet, H. C. W., Terwee, C. B., Mokkink, L. B., \& Knol, D. L. (2011). Measurement in medicine: a practical guide. Cambridge University Press. https://doi.org/10.1017/CBO9780511996214

Dholakia, U. M. (2000). Temptation and resistance: An integrated model of consumption impulse formation and enactment. Psychology and Marketing, 17(11), 955-982. https://doi.org/10.1002/1520-6793(200011)17:11<955::AIDMAR3>3.0.CO;2-J

Eder, R. (2002). Pharmacy checkstand is prime spot to encourage impulse purchases, 24(15). http://connection.ebscohost. com/c/articles/7813091/pharmacy-checkstand-prime-spotencourage-impulse-purchases

Fatima, D. (2013). Impact of organized retailing on Unorganised retailing in India (Vols. 1-321). University of Lucknow.

FICCI. (2020). Retail \& internal trade. Federation of Indian Chambers of Commerece and Industry. http://www.ficci.in/sector.asp?sectorid=33

Foroughi, A., Buang, N. A., Senik, Z. C., Hajmirsadeghi, R. S., \& Bagheri, M. M. (2014). The causes of impulse buying behavior 
among Iranian shoppers. Asian Social Science, 10(21), 64-72. https://doi.org/10.5539/ass.v10n21p64

Ghani, U., \& Kamal, Y. (2010). The impact of in-store stimuli on the impulse purchase behaviour of consumers in Pakistan. The Interdiscplinary Journal of Contemporary Research in Business, 8(2), 155-160. https://www.researchgate.net/publication/308025362_The_Impact_of_In-Store_Stimuli_on_the Impulse_Purchase_Behaviour_of_Consumers_in_Pakistan

Ghosh, P., Tripathi, V., \& Kumar, A. (2010). Customer expectations of store attributes: A study of organized retail outlets in India. Journal of Retail and Leisure Property, 9(1), 75-87. https://doi.org/10.1057/rlp.2009.27

Global Data Lab. (2019). Subnational Human Development Index (4.0). Institute for Management Research, Radboud University. https://globaldatalab.org/shdi/shdi/IND/?interpolation= 0\&extrapolation $=0$ \&nearest_real $=0 \% 0 \mathrm{Ahttps}$ :/globaldatalab . org/shdi/shdi/

Gupta, S., Xu, H., \& Sahu, V. (2009). Impact of store size on impulse purchase. The IUP Journal of Marketing Management, 1-16. https://www.iupindia.in/209/IJMM_Impulse_Purchase_7.html

Harmancioglu, N., Finney, R. Z., \& Joseph, M. (2009). Impulse purchases of new products: An empirical analysis. Journal of Product and Brand Management, 18(1), 27-37. https://doi.org/10.1108/10610420910933344

Hawaldar, I. T., Ullal, M. S., Birau, F. R., \& Spulbar, C. M. (2019). Trapping fake discounts as drivers of real revenues and their impact on consumer's behavior in India: A case study. Sustainability, 11(17), 4637. https://doi.org/10.3390/su11174637

Hilliard, M. (2014). Food products in Impulse buying areas of Grocery Stores: Is temptation making Americans obese? Texas A\&M University. https://oaktrust.library.tamu.edu/bitstream/ handle/1969.1/157597/HILLIARD-DOCUMENT-2014. pdf? isAllowed $=y \&$ sequence $=1$

Hu, H., \& Jasper, C. R. (2006). Social cues in the store environment and their impact on store image. International Journal of Retail and Distribution Management, 34(1), 25-48. https://doi.org/10.1108/09590550610642800

Husnain, M., Rehman, B., Syed, F., \& Akhtar, M. W. (2019). Personal and in-store factors influencing impulse buying behavior among generation $\mathrm{Y}$ consumers of small cities. Business Perspectives and Research, 7(1), 92-107.

https://doi.org/10.1177/2278533718800625

IBEF. (2018). Karnataka: The Silicon Valley of India (Issue April). https://www.ibef.org/download/Karnataka-April-20181.pdf

IBEF. (2019). Retail. India Brand Equity Foundation. https://www.ibef.org/download/retail-jan-2019.pdf

IBEF. (2020). About Karnataka: information on tourism industry, exports, economy \& geography. India Brand Equity Foundation. https://www.ibef.org/states/karnataka.aspx

Iyer, E. S. (1989). Unplanned purchasing: Knowledge of shopping environment and time pressure. Journal of Retailing, 65(1), 40-57.

Iyer, E. S., \& Ahlawat, S. S. (1987). Deviations from a Shopping Plan: When and Why do consumers not buy items as planned. Advances in Consumer Research, 14(1), 246-250.

Jones, M. A., Reynolds, K. E., Weun, S., \& Beatty, S. E. (2003). The product-specific nature of impulse buying tendency. Journal of Business Research, 56(7), 505-511. https://doi.org/10.1016/S0148-2963(01)00250-8

Kacen, J. J., \& Lee, J. A. (2002). The influence of culture on consumer impulsive buying behavior. Journal of Consumer Psychology, 12(2), 163-176.

https://doi.org/10.1207/153276602760078686
Karmali, N. (2007, December). "Meet Coke's next boss? An interview with Muhtar Kent, CEO - Coca Cola." Business India, December, 18.

Kollat, D. T., \& Willett, R. P. (1967). Customer impulse purchasing behavior. Journal of Marketing, 4(1), 21-31. https://doi.org/10.1177/002224376700400102

Kollat, D. T., \& Willett, R. P. (1969). Is impulse purchasing really a useful concept for marketing decisions? Journal of Marketing, 33(1), 79-83. https://doi.org/10.2307/1248750

Kotler, P. (1974). Atmospherics as a marketing tool. Journal of Retailing, 49, 48-64.

KPMG. (2018). India soars higher. https://home.kpmg.com/content/dam/kpmg/au/pdf/2018/india-soars-higher-2018.pdf

Lin, Y. H., \& Chen, C. Y. (2012). Adolescents' impulse buying: Susceptibility to interpersonal influence and fear of negative evaluation. Social Behavior and Personality, 40(3), 353-358. https://doi.org/10.2224/sbp.2012.40.3.353

Luo, X. (2005). How does shopping with others influence impulsive purchasing? Journal of Consumer Psychology, 15(4), 288-294. https://doi.org/10.1207/s15327663jcp1504_3

Maister, D. H. (1985). The Psychology of waiting lines. In J. Czepiel, M. A. Solomon, \& C. F. Surprenant (Eds.), The service encounter: managing employee/customer interaction in service businesses (pp. 113-123). Lexington Books. https://doi.org/10.1080/15287390152103634

Mischel, H. N., \& Mischel, W. (1983). The development of children's knowledge of self-control strategies. Child Development, 54(3), 603-619. https://doi.org/10.2307/1130047

Mohan, G., Sivakumaran, B., \& Sharma, P. (2013). Impact of store environment on impulse buying behavior. European Journal of Marketing, 47(10), 1711-1732. https://doi.org/10.1108/EJM-03-2011-0110

MSME-Development Institute. (2016). Karnataka State Industrial Profile 2015-2016. MSME-Development Institute. http://dcmsme.gov.in/dips/state_wise_dips/state_profile_karnatka_11316.pdf

NASSCOM. (2017). NASSCOM - AT Kearney Reveal Karnataka IT Potential. Firstpost. https://www.firstpost.com/business/biztech/nasscom-at-kearney-reveal-karnataka-it-potential-1866589.html

Nathanson, J. (2013). Are Smartphones making us less impulsive? Priceonomics. https://priceonomics.com/are-smartphonesmaking-us-less-impulsive/

Nethravathi, P. S. R., Bai, G. V., Spulbar, C., Suhan, M., Birau, R., Calugaru, T., Hawaldar, I. T. \& Ejaz, A. (2020). Business intelligence appraisal based on customer behaviour profile by using hobby-based opinion mining in India: A case study. Economic Research-Ekonomska Istraživanja, 33(1), 1889-1908. https://doi.org/10.1080/1331677X.2020.1763822

Omar, O., \& Kent, A. (2001). International airport influences on impulsive shopping: Trait and normative approach. International Journal of Retail \& Distribution Management, 29(5), 226-235. https://doi.org/10.1108/09590550110390887

Park, C. W., Iyer, E. S., \& Smith, D. C. (1989). The effects of situational factors on in-store grocery shopping behavior: the role of store environment and time available for shopping. Journal of Consumer Research, 15(4), 422-433. https://doi.org/10.1086/209182

Pataskar, S. A. (2011). A study of organised retail business in selected cities in Western Maharashtra. Shivaji University, Kolhapur. http://hdl.handle.net/10603/23546

Peck, J., \& Childers, T. L. (2006). If I touch it I have to have it: Individual and environmental influences on impulse purchasing. Journal of Business Research, 59(6), 765-769. https://doi.org/10.1016/j.jbusres.2006.01.014 
Piron, F. (1991). Defining impulse purchasing. Advances in Consumer Research, 18(1951), 509-514.

Pradhan, V. (2016). Study on impulsive buying behavior among consumers in supermarket in Kathmandu Valley. Journal of Business and Social Sciences Research, 1(2), 215-233. https://doi.org/10.3126/jbssr.v1i2.20926

Pugliese, T. (1998, April). Improving impulse potential [at the checkout counter]. Marketing Magazine, 103(16), 18. https:// search.proquest.com/docview/227164218? accountid=193930

Raju, Kv., Kumar, Dp., \& Srinivasa Raju, S. (2015). A comprehensive review of impulse purchase process and various factors affecting it. IOSR Journal of Business and Management, 17(12), 81-107.

Rook, D. W. (1987). The buying impulse. Journal of Consumer Research, 14(2), 189-199. https://doi.org/10.1086/209105

Rook, D. W., \& Fisher, R. J. (1995). Normative influences on impulsive buying behavior. Journal of Consumer Research, 22(3), 305-313. https://doi.org/10.1086/209452

Rook, D. W., \& Hoch, S. J. (1985). Consuming impulses. Advances in Consumer Research, NA-12, 23-27. https://www. acrwebsite.org/volumes/6351/volumes/v12/NA-12

Sandoval, L., \& Sawant, A. (2019). Retail sector expansion creates new opportunities for high-value products. In GAIN Report, United States Department of Agriculture. https://apps.fas.usda. gov/newgainapi/api/report/downloadreportbyfilename?filena me=Retail\%20Foods_New\%20Delhi_India_7-17-2019.pdf

Schimmel, M., \& Bekker, R. (2013). Deployment of express checkout lines at supermarkets. https://beta.vu.nl/nl/Images/werkstuk-schimmel_tcm235-335266.pdf

Schwarz, N., \& Bohner, G. (1996). Feelings and their motivational implications: Moods and the action sequence. In P. Gollwitzer \& J. Bargh (Eds.), The psychology of action: Linking cognition and motivation to behavior (pp. 119145). The Guilford Press. http://search.ebscohost.com/ login.aspx?direct $=$ true $\& d b=$ psyh $\& A N=1996-98326-$ 006\&site=ehost-live

Sharma, P., Sivakumaran, B., \& Marshall, R. (2010). Impulse buying and variety seeking: A trait-correlates perspective. Journal of Business Research, 63(3), 276-283. https://doi.org/10.1016/j.jbusres.2009.03.013

Sherman, E., Mathur, A., \& Smith, R. B. (1997). Store environment and consumer purchase behavior: Mediating role of consumer emotions. Psychology and Marketing, 14(4), 361-378. https:// doi.org/10.1002/(SICI)1520-6793(199707)14:4<361::AIDMAR4>3.0.CO;2-7

Shimp, T. A., \& DeLozier, M. W. (1986). Promotion management and marketing communications. Dryden press. https://doi.org/10.1080/00913367.1986.10673045

Stern, H. (1962). The significance of impulse buying today. Journal of Marketing (Pre 1986), 26(2), 59-62. https://doi.org/10.1177/002224296202600212

Streiner, D. L., Norman, G. R., \& Cairney, J. (2015). Health measurement scales: a practical guide to their development and use (5th ed.). Oxford University Press. https://doi.org/10.1093/med/9780199685219.001.0001

Suneera, T. (2019). Deloitte sees share of organised retail at $22 \%$ by 2021 . Livemint. https://www.livemint.com/industry/retail/deloitte-sees-share-of-organised-retail-at22-by-2021-1551176724113.html
Tauber, E. M. (1972). Why do people shop? Journal of Marketing, 36(4), 46-59. https://doi.org/10.2307/1250426

Taylor, S. (1994). Waiting for service: the relationship between delays and evaluations of service. Journal of Marketing, 58(2), 56-69. https://doi.org/10.2307/1252269

Ullal, M. S., Hawaldar, I. T., Mendon, S., \& Joseph, N. (2020). The effect of artificial intelligence on the sales graph in the Indian market. Entrepreneurship and Sustainability Issues, 7(4), 2940-2954. https://doi.org/10.9770/jesi.2020.7.4(24)

Ullal, M., \& Hawaldar, I. T. (2018). Influence of advertisement on customers based on the AIDA model. Problems and Perspectives in Management, 16(4), 285-298. https://doi.org/10.21511/ppm.16(4).2018.24

Ullal, M. S., Spulbar, C., Hawaldar, I. T., Popescu, V., Birau, R. (2021). The impact of online reviews on e-commerce sales in India: A case study. Economic Research-Ekonomska Istraživanja, 34(1), 1-15. https://doi.org/10.1080/1331677X.2020.1865179

Van Riel, A. C. R., Semeijn, J., Ribbink, D., \& Bomert-Peters, Y. (2012). Waiting for service at the checkout: Negative emotional responses, store image and overall satisfaction. Journal of Service Management, 23(2), 144-169.

https://doi.org/10.1108/09564231211226097

Vinish, P., Pinto, P., Hawaldar, I. T. \& Pinto, S. (2020). Impulse buying behavior among female shoppers: Exploring the effects of selected store environment elements. Innovative Marketing, 16(2), 54-70. https://doi.org/10.21511/im.16(2).2020.05

Vinish, P., Pinto, P., Hawaldar, I. T., Pinto, S. (2021). Antecedents of behavioral intention to use online food delivery services: An empirical investigation. Innovative Marketing, 17(1), 1-15. https://doi.org/10.21511/im.17(1).2021.01

Weiss, E. N., \& Tucker, C. (2018). Queue management: Elimination, expectation, and enhancement. Business Horizons, 61(5), 671-678. https://doi.org/10.1016/j.bushor.2018.05.002

Weun, S., Jones, M. A., \& Beatty, S. E. (1998). Development and validation of the impulse buying tendency scale. Psychological Reports, 82(3), 1123-1133. https://doi.org/10.2466/PR0.82.3.1123-1133

Wheatley, J. J., \& Chiu, J. S. Y. (1977). The effects of price, store image, and product and respondent characteristics on perceptions of quality. Journal of Marketing Research, 14(2), 181-186. https://doi.org/10.2307/3150467

Yoo, C., Park, J., \& MacInnis, D. J. (1998). Effects of store characteristics and in-store emotional experiences on store attitude. Journal of Business Research, 42(3), 253-263. https://doi.org/10.1016/S0148-2963(97)00122-7

Youn, S., \& Faber, R. J. (2000). Impulse buying: its relation to personality traits and cues. Advances in Consumer Research, 27(1), 179-185.

Yu, C., \& Bastin, M. (2010). Hedonic shopping value and impulse buying behavior in transitional economies: A symbiosis in the Mainland China marketplace. Journal of Brand Management, 18(2), 105-114. https://doi.org/10.1057/bm.2010.32

Zhou, L., \& Wong, A. (2003). Consumer impulse buying and in-store stimuli in Chinese supermarkets. Journal of International Consumer Marketing, 16(2), 37-53. https://doi.org/10.1300/J046v16n02_03 